\title{
HOW GROWTH DECELERATION IN THE PEOPLE'S REPUBLIC OF CHINA AFFECTS OTHER ASIAN ECONOMIES: AN EMPIRICAL ANALYSIS
}

Minsoo Lee, Donghyun Park, and Arief Ramayandi

NO. 484

May 2016
ADB ECONOMICS WORKING PAPER SERIES 
ADB Economics Working Paper Series

\section{How Growth Deceleration in the People's Republic of China Affects Other Asian Economies: An Empirical Analysis}

Minsoo Lee, Donghyun Park, and Arief Ramayandi

No. 484 | May 2016
Minsoo Lee (mlee@adb.org) is senior economist, Donghyun Park (dpark@adb.org) is principal economist, and Arief Ramayandi (aramayandi@adb.org) is senior economist at the Economic Research and Regional Cooperation Department of the Asian Development Bank. 
Asian Development Bank

6 ADB Avenue, Mandaluyong City

1550 Metro Manila, Philippines

www.adb.org

(C) 2016 by Asian Development Bank

May 2016

ISSN 2313-6537 (Print), 2313-6545 (e-ISSN)

Publication Stock No. WPS168036-2

The views expressed in this paper are those of the authors and do not necessarily reflect the views and policies of the Asian Development Bank (ADB) or its Board of Governors or the governments they represent.

ADB does not guarantee the accuracy of the data included in this publication and accepts no responsibility for any consequence of their use.

By making any designation of or reference to a particular territory or geographic area, or by using the term "country" in this document, $A D B$ does not intend to make any judgments as to the legal or other status of any territory or area.

Note: In this publication, "\$” refers to US dollars.

The ADB Economics Working Paper Series is a forum for stimulating discussion and eliciting feedback on ongoing and recently completed research and policy studies undertaken by the Asian Development Bank (ADB) staff, consultants, or resource persons. The series deals with key economic and development problems, particularly those facing the Asia and Pacific region; as well as conceptual, analytical, or methodological issues relating to project/program economic analysis, and statistical data and measurement. The series aims to enhance the knowledge on Asia's development and policy challenges; strengthen analytical rigor and quality of ADB's country partnership strategies, and its subregional and country operations; and improve the quality and availability of statistical data and development indicators for monitoring development effectiveness.

The ADB Economics Working Paper Series is a quick-disseminating, informal publication whose titles could subsequently be revised for publication as articles in professional journals or chapters in books. The series is maintained by the Economic Research and Regional Cooperation Department. 


\section{CONTENTS}

TABLES AND FIGURES

ABSTRACT V v v v v v

I. THE PEOPLE'S REPUBLIC OF CHINA AS AN ENGINE OF GROWTH

FOR DEVELOPING ASIA

II. SLOWDOWN IN THE PEOPLE'S REPUBLIC OF CHINA AS A DRAG ON ASIAN GROWTH?

III. SELECTIVE LITERATURE REVIEW

IV. THE GROWING IMPORTANCE OF THE PEOPLE'S REPUBLIC OF CHINA AS A TRADING PARTNER AND EXPORT MARKET

V. THE IMPACT OF THE PEOPLE'S REPUBLIC OF CHINA SLOWDOWN ON GROWTH IN ASIA: AN EMPIRICAL ASSESSMENT

A. The Trade Channel Approach 9

B. Global Vector Autoregressive Analysis 12

C. Further Discussion of the Empirical Results 13

D. Knock-on Effects from Further Slowdown in the People's Republic of China in 2013-2014

$\begin{array}{lll}\text { VI. } & \text { CONCLUDING OBSERVATIONS }\end{array}$

$\begin{array}{ll}\text { REFERENCES } & 19\end{array}$ 


\section{TABLES AND FIGURES}

\section{TABLES}

$1 \quad$ Panel Analysis with a Fixed Effect Model: The Effect of a PRC Slowdown

10

$2 \quad$ Estimated Growth Gap, 2013 and 2014

\section{FIGURES}

1 GDP and GDP per Capita in the PRC 2

2 Real GDP Growth in the PRC 3

3 Average Annual Real Import Growth Rate in the PRC 4

$4 \quad$ Developing Asia GDP Growth, Quarterly Average 5

5 Composition of Developing Asia's Exports to the PRC (\$ billion) 7

6 Composition of Developing Asia's Exports to the PRC (\% of total exports) 7

7 Developing Asia's Exports to the PRC (\% of all exports) 8

8 Developing Asia's Exports to the PRC (\% of GDP) 8

9 Exports from Developing Asia to the US and the PRC 10

10 Impact of 1 Percentage Point Growth Slowdown in the PRC

11 Impact of 1 Percentage Point Growth Slowdown in the PRC on Selected Asian Economies, 2007-2012 12

12 Impact of GDP Growth 1 Percentage Point Lower than the Baseline in the PRC 13

13 Isolating the PRC Effects 16 


\begin{abstract}
Developing Asia has benefited greatly from the rise of the People's Republic of China (PRC), primarily through the trade channel. The PRC and its neighbors have collectively formed a regional production network, and the PRC is becoming an increasingly important source of final demand. Two empirical methodologies are used to examine the likely economic impact of growth deceleration in the PRC on other Asian economies: (i) a single-equation approach that captures the trade channel and (ii) a global vector autoregressive model that captures the effects beyond just the trade channel. The results of both analyses confirm that deceleration in the PRC will indeed have a non-negligible negative effect on other economies, especially on East and Southeast Asia. An out-of-sample analysis to tease out the effect of slower growth in the PRC from the recent growth performance of selected Southeast Asian economies suggests that the PRC effect is contributing to the growth dynamics of this region but is not always dominant.
\end{abstract}

Keywords: Asia, growth, People's Republic of China, spillover, trade

JEL code: F43 


\section{THE PEOPLE'S REPUBLIC OF CHINA AS AN ENGINE OF GROWTH FOR DEVELOPING ASIA}

Since momentous economic reforms initiated in 1978 to move the People's Republic of China (PRC) away from a centrally planned economy to a market-based economy, the PRC economy has grown by leaps and bounds. In fact, the PRC has been since then one of the world's fastest growing economies. The sustained rapid growth of the PRC and its transformation into an economic heavyweight is one of the most significant trends in the global economic landscape in the past few decades. Its world-beating growth performance post-1978 has been driven to a large extent by labor-intensive, export-oriented industrialization. After the PRC opened its doors to the outside world, foreign investment poured in to take advantage of its seemingly infinite supply of low-wage unskilled workers to manufacture goods for export to foreign markets. The rise of the private sector and a concomitant decline in the state sector was another key trend.

Above all, sustained rapid growth in the PRC has benefited the local people. General living standards have improved hugely to provide an immeasurably higher quality of life than in 1978 . Further, the proportion of those who live in poverty in the PRC has declined sharply. The PRC is not alone in riding export-oriented industrialization to economic success, as it follows in the footsteps of Japan, the newly industrialized economies, and some members of the Association of Southeast Asian Nations. Yet, from a global perspective, rapid growth in the PRC matters much more than it would in, say, the Republic of Korea, because of sheer size. The PRC is, after all, the world's most populous country, with over 1 billion people, and in 2010 it overtook Japan as the world's second biggest economy. Predictably, the rise of the PRC has reverberated across the world. For example, its robust demand for raw materials contributed to the global commodities boom, benefiting countries in distant Africa and Latin America.

But it was closer to home in Asia where the rise of the PRC has been felt most strongly. In particular, the PRC has extensive trade, investment, and other economic links with East and Southeast Asia. Foreign direct investment from Hong Kong, China; Japan; the Republic of Korea; Taipei,China; and other neighbors was a key early catalyst of PRC industrialization. As it proceeded, East and Southeast Asia formed a regional production network that exported manufactured goods to the outside world. What came to be dubbed Factory Asia was based on comparative advantage-for example, advanced technology in Japan and abundant cheap labor in the PRC-and enabled all its participants to compete better in the global market. That Factory Asia output was largely destined for the United States (US) and other markets outside the region did not diminish its value for the region. At the same time, resource-rich Asian economies such as Indonesia and Malaysia benefited from a seemingly insatiable appetite in the PRC for commodities.

While the PRC is now the world's second largest economy and poised to overtake the US as the world's largest economy in the not-too-distant future, it will be a long time before the PRC approaches the US in living standards. It is worth remembering that the PRC was a very poor country at the time of its spectacular growth takeoff. Nevertheless, even in terms of living standards, sustained rapid growth has translated into a remarkable improvement (Figure 1). The emergence and expansion of an increasingly affluent middle class with growing purchasing power means that millions of consumers in the PRC now buy cars and laptops, fly commercially, and travel overseas. And they spend a lot during their overseas trips, as evident in the warm welcome they receive from Mandarin-speaking guides at high street fashion stores in London. As a result of its growing wealth, the PRC is no longer just an assembler of parts and components into final goods for reexport to the US and other countries but a globally significant importer of final goods in its own right. For example, Park and Shin (2010) find 
that the share of final goods in imports to the PRC from East and Southeast Asia is rising, and the share of parts and components is declining.

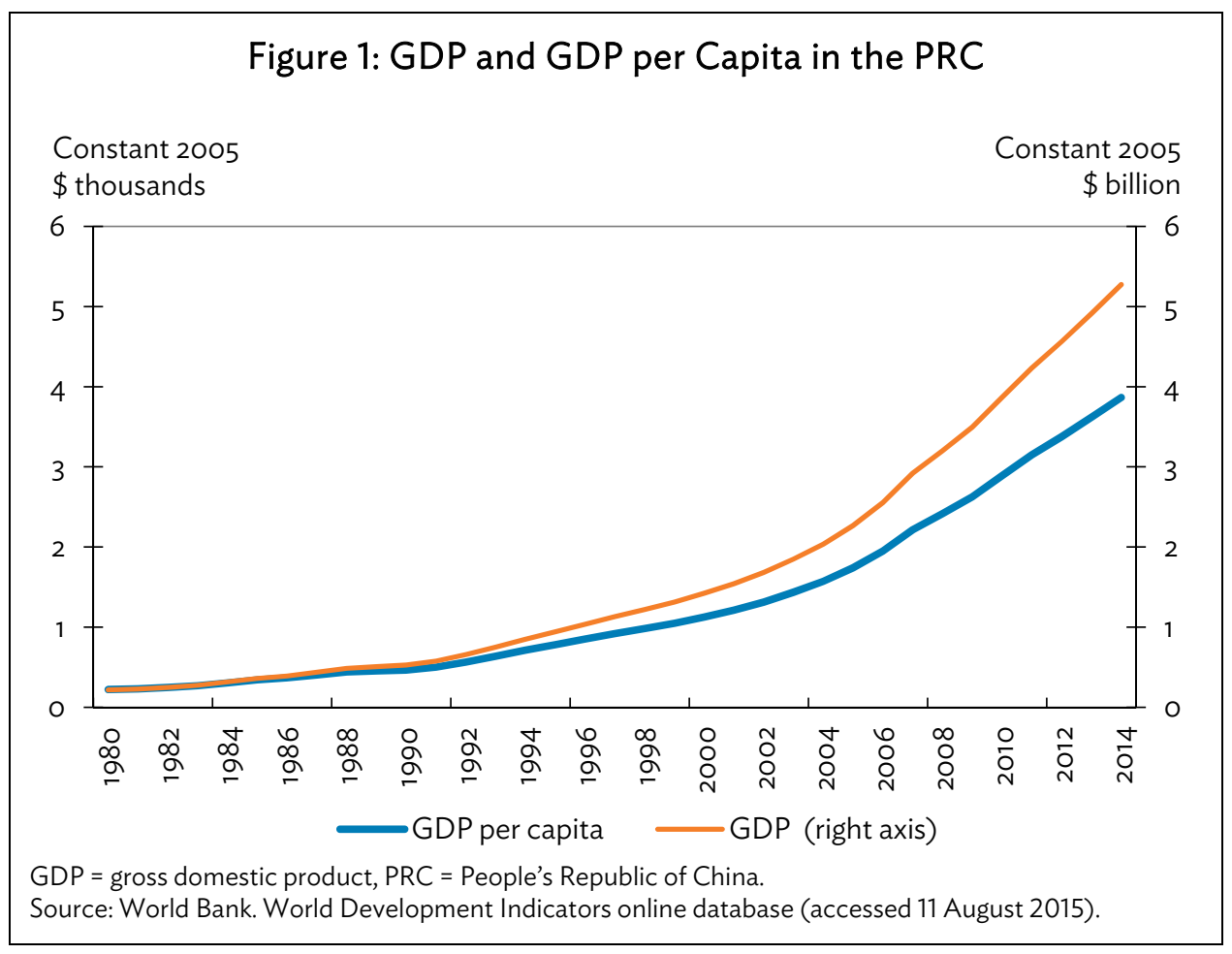

To sum up, sustained rapid growth in the PRC since 1978 and the economy's transformation into a regional and global economic giant have contributed to sustained rapid growth in developing Asia as a whole. The positive economic impact of the spectacular rise of the PRC has been most tangible in the East and Southeast Asian (SEA) economies that collectively form Factory Asia, with the PRC at its center. The impact was not confined to those economies but reverberated across the whole region, for example through the seemingly insatiable demand in the PRC for commodities such as copper from Mongolia and oil from Kazakhstan. Further, its growing affluence and purchasing power has turned the PRC as a significant source of demand from developing Asia for final goods, as opposed to parts and components. Taken together, these trends suggest that the PRC served as an engine of growth for developing Asia. Park and Shin (2011), for example, find evidence of the growing impact of PRC imports on Asia's growth.

\section{SLOWDOWN IN THE PEOPLE'S REPUBLIC OF CHINA AS A DRAG ON ASIAN GROWTH?}

Since the global financial crisis of 2008-2009, the relentless momentum of PRC growth has visibly slowed down (Figure 2). The PRC slowdown is part of a broader global trend toward slower growth since the global crisis, which originated in the advanced economies, specifically in the US subprime mortgage markets. As a result, the crisis hit the advanced economies harder than it did developing countries. Immediately after the crisis, the world economy was characterized by a two-speed recovery, with emerging markets growing faster than advanced economies. More recently, emerging markets have also suffered growth deceleration, generating concerns about a worldwide growth slump and 
giving rise to pessimistic scenarios such as the secular stagnation hypothesis. ${ }^{1}$ The decidedly less benign world economic outlook since the global crisis is impinging on PRC exports and growth. Therefore, one key cause of the PRC slowdown is a less conducive external environment for exports. While the favorable export environment that prevailed before the global crisis contributed to rapid growth in the PRC, the deterioration of the export environment since the global crisis has exacerbated the postcrisis growth slowdown in the PRC.

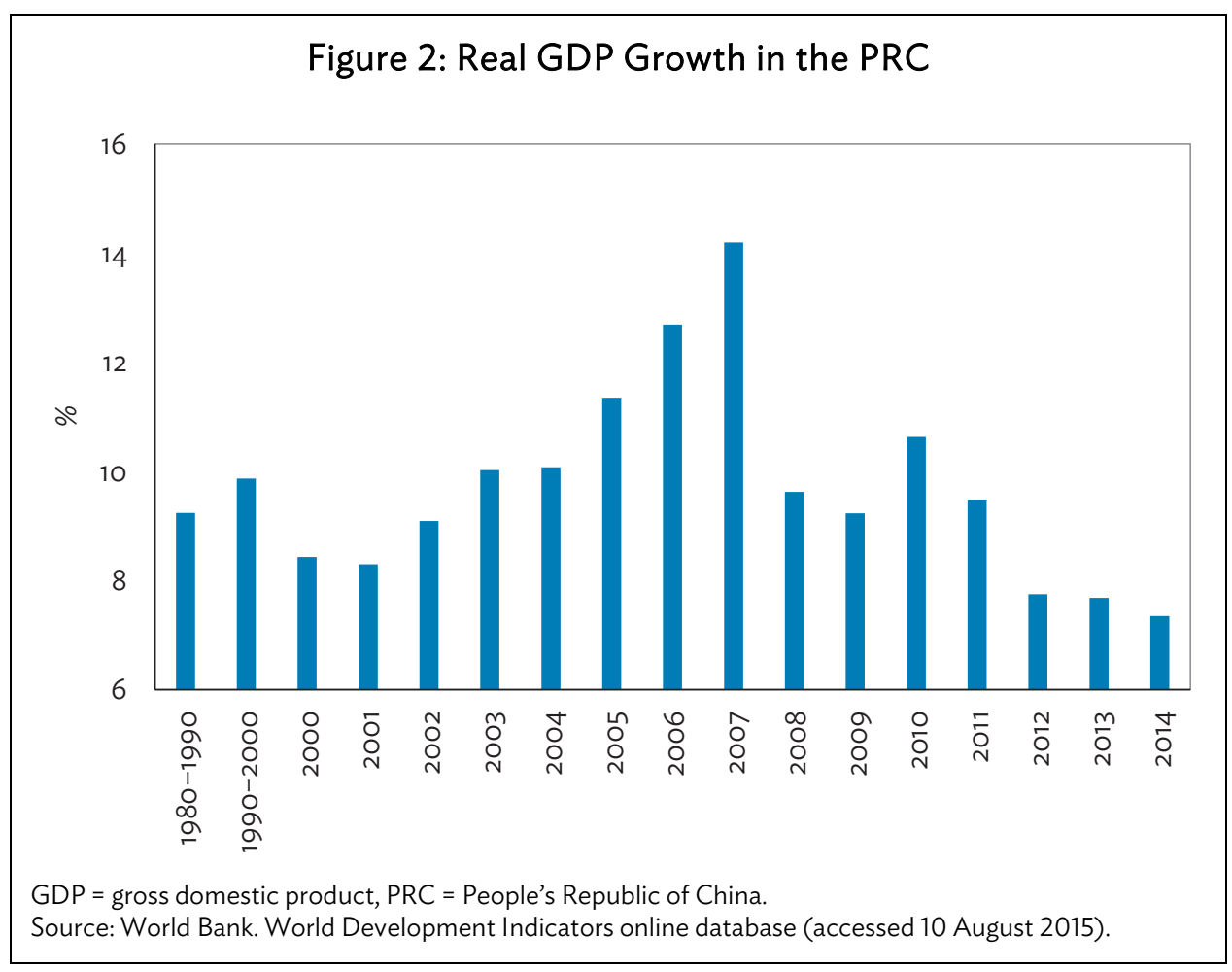

In addition to the less benign external environment, a number of significant homegrown factors are playing a significant role in the PRC slowdown. Above all, the PRC may be a victim of its past success. Its world-beating double-digit economic growth rate since the market reforms of 1978 has transformed the PRC into an upper-middle-income country by the World Bank's definition. Even highly successful economies typically slow down as they transition from low income to middle income due to diminishing marginal returns to capital, the narrowing of the technology gap with advanced economies, the exhaustion of labor supply available for reallocation from low-productivity agriculture to high-productivity manufacturing, and other factors. Indeed Eichengreen, Park, and Shin (2012, 2014) found that in 2011 the PRC was already close to the income level at which growth typically slows. Further, the Government of the PRC seems to have recognized the limits of investment- and exportled growth and is strategically engineering a structural transformation toward a growth paradigm that relies to a greater extent on domestic demand and consumption.

The structural change represents a welcome, healthy, and natural transition toward a somewhat lower but more sustainable growth pattern. As such, in the medium- to long-term, the structural change should benefit both the PRC and its economic partners. Unsustainably rapid growth

\footnotetext{
$1 \quad$ Larry Summers proposed the secular stagnation hypothesis, which suggests that the world economy faces an extended period of very slow economic growth due to weak private investment which is, in turn, due to structural factors such as slow population growth and innovation.
} 
that eventually ends in crisis would be bad for both the PRC and the world economy, but slower growth in the PRC is also bound to have adverse global repercussions in the short-term. For example, the wild roller coaster volatility of PRC stock markets in 2015 was felt even in US stock markets, reflecting concerns around the world about a sudden and sharp deceleration of growth in the PRC. Above all, slower growth there will inevitably wean the PRC of its robust appetite for imports-from commodities to intermediate goods and final goods-affecting advanced and emerging markets alike (Figure 3). While the less favorable global outlook adversely affects PRC exports and growth, the PRC is now a globally significant importer in its own right, which means that slower growth there will hurt other economies' exports and growth. The negative impact will be felt around the world, affecting in particular rich countries' exports of high-tech machinery and poor countries' exports of commodities.

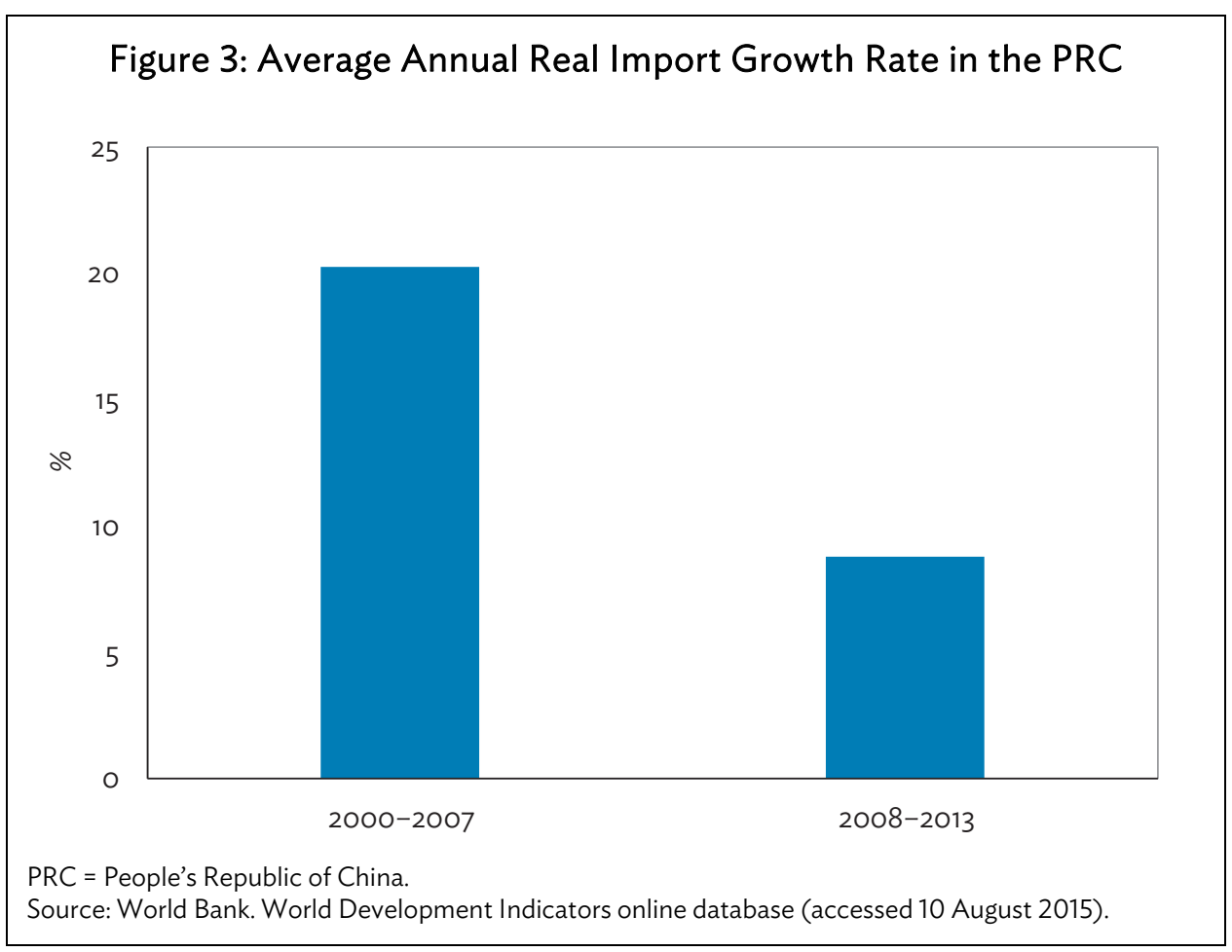

Developing Asia too will be adversely affected by the PRC slowdown, just as it benefited from rapid growth in the past. While the whole region will feel the impact of the PRC slowdown, some subregions and economies will be hit harder than others. In particular, the effect will be more pronounced in East Asian economies that have extensive trade and other economic links with the PRC (Figure 4). These economies, together with Southeast Asia, form a regional production network that is a vital cog in the global value chain. On the other hand, India and other South Asian economies will likely be less affected because their links with the PRC are limited. Despite the growing importance of the PRC as a source of investment, the primary channel through which it affects the region is trade. Slowing growth and a declining appetite for imports will affect developing Asia's exports of commodities, parts and components, and final goods, thus affecting regional economies at all income levels. 


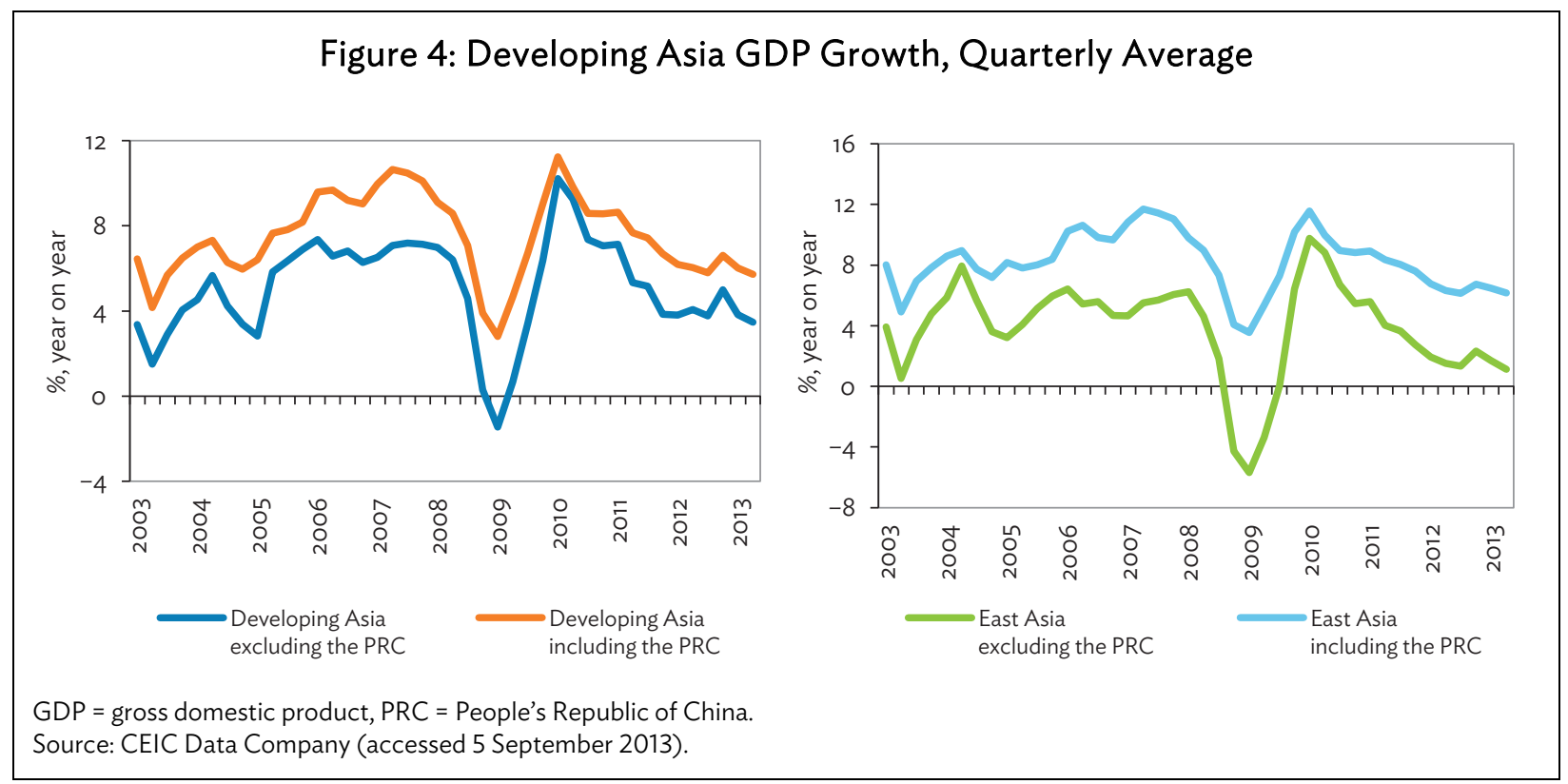

\section{SELECTIVE LITERATURE REVIEW}

This section briefly reviews a number of relevant studies. The magnitude of the impact of the PRC slowdown on the exports and growth of other Asian economies will clearly depend on the magnitude of the slowdown. A deeper slowdown will obviously have a larger adverse effect. There is a wide range of views about the future economic prospects for the PRC and its potential growth rate. For example, based on a simple numerical simulation that takes into account some key PRC-relevant relationships such as that between urbanization and investment, Yuan et al. (2013) predicted that growth will slow to the $5.7 \%-6.6 \%$ range in $2016-2020$ and further to the $5.4 \%-6.3 \%$ range in $2020-2030$. These predictions may be somewhat optimistic, as their simulation predicted growth at $7.8 \%-8.7 \%$ in $2011-$ 2015 , which is higher than likely actual growth rates. The paper pointed out that the key to mitigating the adverse impact of an aging population lies in improving labor productivity.

Li and Lou (2015) estimated potential economic growth in the PRC during 2015-2025 under three scenarios. In the optimistic scenario, the real annual gross domestic product (GDP) growth rate was predicted to average at $7.2 \%$ in $2016-2020$ and $6.6 \%$ in $2021-2025$. The corresponding figures were $6.8 \%$ and $6.1 \%$ for the benchmark scenario and $6.4 \%$ and $5.7 \%$ for the pessimistic scenario. The analysis reviewed the major factors affecting potential economic growth in the PRC and used an integrated economic model consisting of system dynamics, econometrics, and input-output to forecast the size and structure of the PRC economy by 2025. Although the deterioration of the global economic outlook and a diminishing demographic dividend in the PRC were found to pose formidable challenges, the study indicated that the PRC can grow at a healthy pace if helped by a multipronged approach based on urbanization, investment in research and development and in education, total factor productivity improvement, service sector development, and expanded consumption.

Park and Shin (2010) analyzed trade data to assess the role of the PRC as an engine of growth for economies in East and Southeast Asia that trade a lot with the PRC. Whether PRC imports from its neighbors have an independent positive impact on their growth depends ultimately on the nature of 
those imports - that is, whether those imports (i) are derived from demand for final goods in the US and other industrialized countries or (ii) reflect demand within the PRC for final goods. Obviously, the greater the relative importance of demand within the PRC, as opposed to demand derived from demand in the US and other countries, the stronger role the PRC plays as an engine of growth. Critically, the analyzed trade data show a sustained shift from parts and components toward final goods in the composition of PRC imports from its neighbors, which suggests that the PRC is becoming more of a consumer and less of an assembler.

In another study, Park and Shin (2011) assessed the PRC role as an engine of growth differently by using vector autoregression (VAR) models to investigate the impact of exports to the PRC on the GDPs of Hong Kong, China; Indonesia; the Republic of Korea; Malaysia; Singapore; Taipei,China; and Thailand. The evidence from a three-variable VAR model indicates that exports to the PRC have a large and growing positive effect on the GDPs of its neighbors. Furthermore, this effect has grown larger since the Asian crisis and even more so since the global financial crisis. Using a four-variable VAR model, the positive impact of PRC imports remains significant to shorter time horizons. The evidence therefore indicates that exports to the PRC contributed to Asian economies' recovery from the global financial crisis and, more generally, are beginning to become an engine of growth for the region.

Ahuja and Nabar (2012) empirically examined the spillover effects of a specific dimension of the PRC growth slowdown: deceleration of investment. A key feature of the growth paradigm in the PRC has been heavy reliance on investment as a driver of growth. Economies that benefited from high investment in the PRC in the past-for example, exporters of commodities, capital goods, and parts and components-now face risks from a deceleration of investment. The study quantified the potential global spillover from an investment slowdown in the PRC, finding a 1 percentage point slowdown in investment in the PRC associated with a reduction of global growth of 0.1 percentage points. East and SEA economies that are part of the regional production network and commodity exporters would suffer the most from lower investment in the PRC. In addition, spillover also registers strongly across a range of macroeconomic, trade, and financial variables among trading partners in the Group of 20.

\section{THE GROWING IMPORTANCE OF THE PEOPLE'S REPUBLIC OF CHINA AS A TRADING PARTNER AND EXPORT MARKET}

The rise of the PRC as a global economic heavyweight closely parallels its rise as a global trading power. The PRC is increasingly important in developing Asia's trading system, not only as an exporter but also as an importer. In particular, since joining the World Trade Organization in 2001, the PRC has emerged as an important destination for exports from other Asian economies, especially those in East and Southeast Asia. The value of developing Asia's exports of machinery, metals, chemicals, and minerals to the PRC have steadily increased to $\$ 122$ billion in 2012 from $\$ 56$ billion in 2004 (Figure 5). Chemicals are imported mostly from Hong Kong, China; the Republic of Korea; Singapore; and Taipei,China, and machinery imports are mainly from Taipei,China. Machinery, metals, chemicals, and minerals collectively account for about $20 \%$ of developing Asia's total exports to the PRC (Figure 6).

The share of exports to the PRC in developing Asia's total export rose by half from $14 \%$ in 2002 to $21 \%$ in 2012 (Figure 7). As a share of GDP, exports to the PRC rose from $6 \%$ to $10 \%$ in the same period (Figure 8). The four newly industrialized economies-Hong Kong, China; the Republic of Korea; Singapore; and Taipei,China-are the most vulnerable to a sharp slowdown in the PRC, as they are all 
major exporters of capital goods to the PRC. Further, slower growth in the PRC will dampen demand for key commodities such as copper, iron, and other minerals, putting downward pressure on their prices. Asia's net commodity exporters, such as Indonesia, Malaysia, and Turkmenistan, will thus be adversely affected. A sizable portion of PRC imports from its neighbors are parts and components for assembly and reexport to the US and other world markets, but a large and growing share is final goods (Park and Shin 2010). Therefore, the PRC slowdown will have a more direct impact on imports from the region.

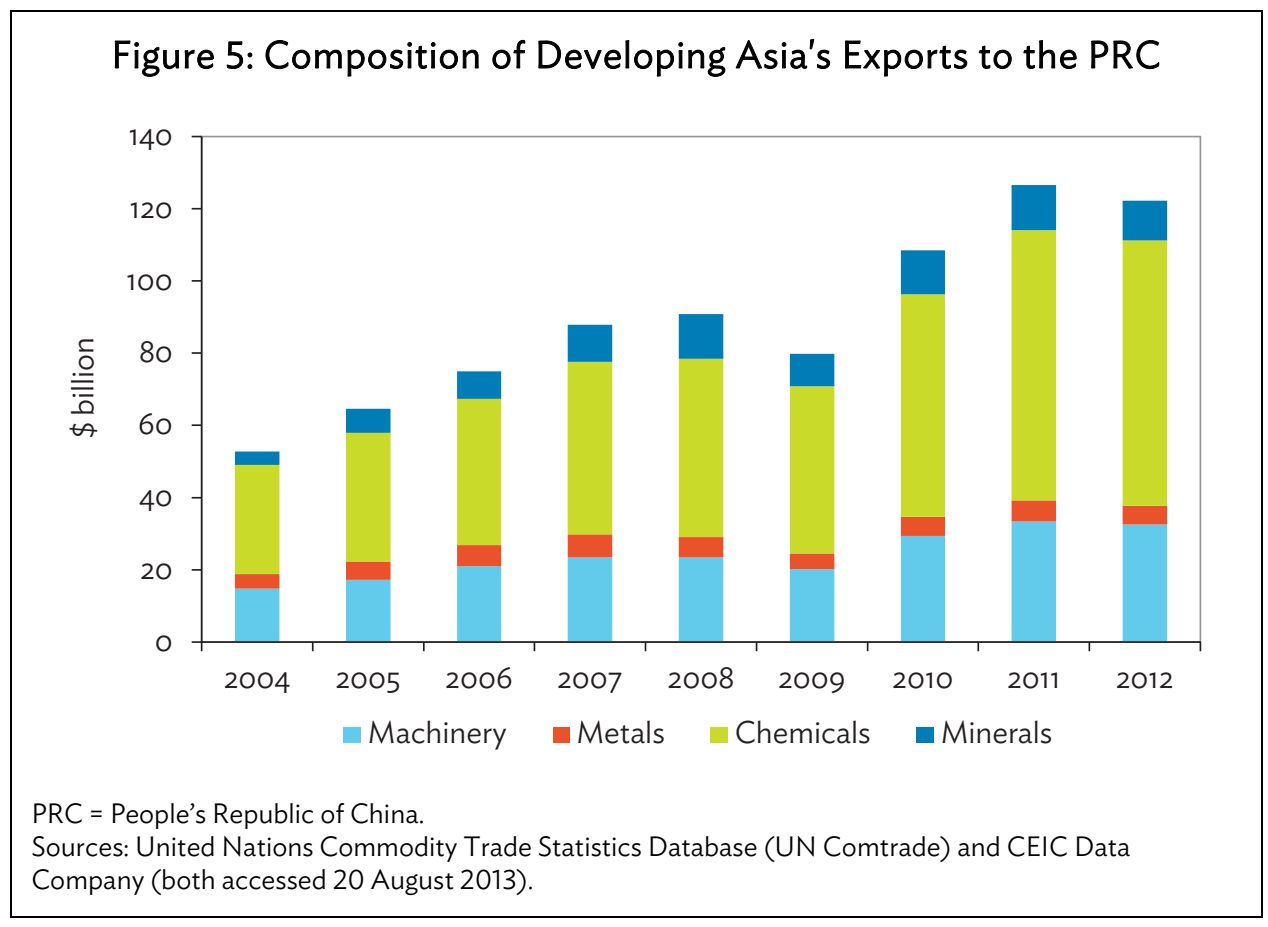

Figure 6: Composition of Developing Asia's Exports to the PRC

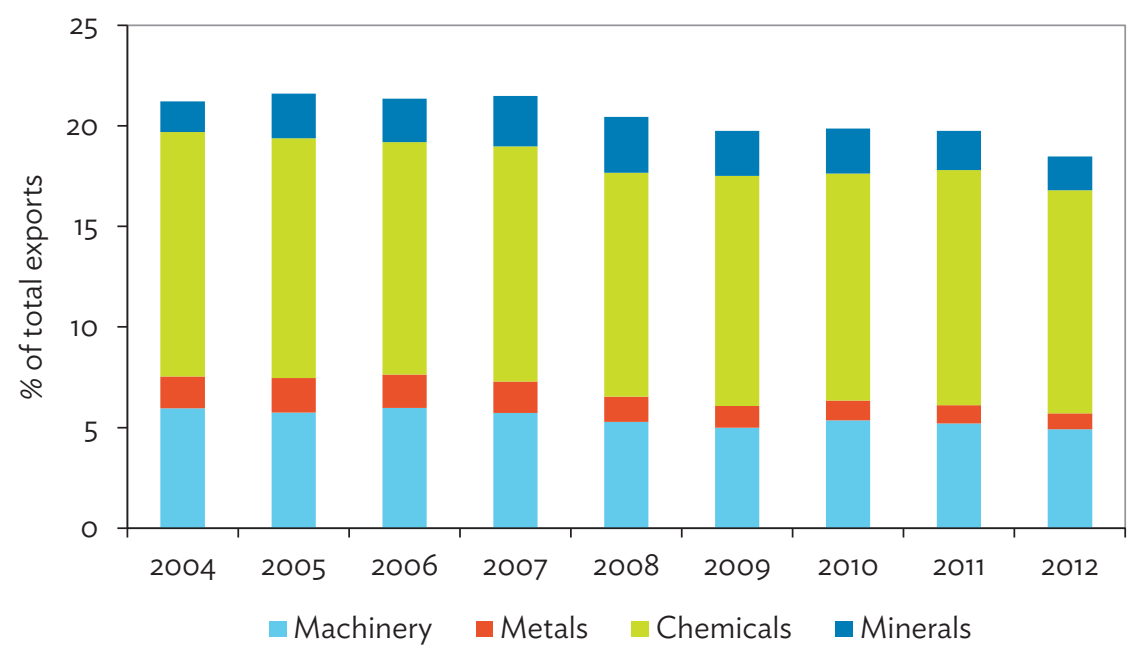

PRC $=$ People's Republic of China

Sources: United Nations Commodity Trade Statistics Database (UN Comtrade) and CEIC Data Company (both accessed 20 August 2013). 

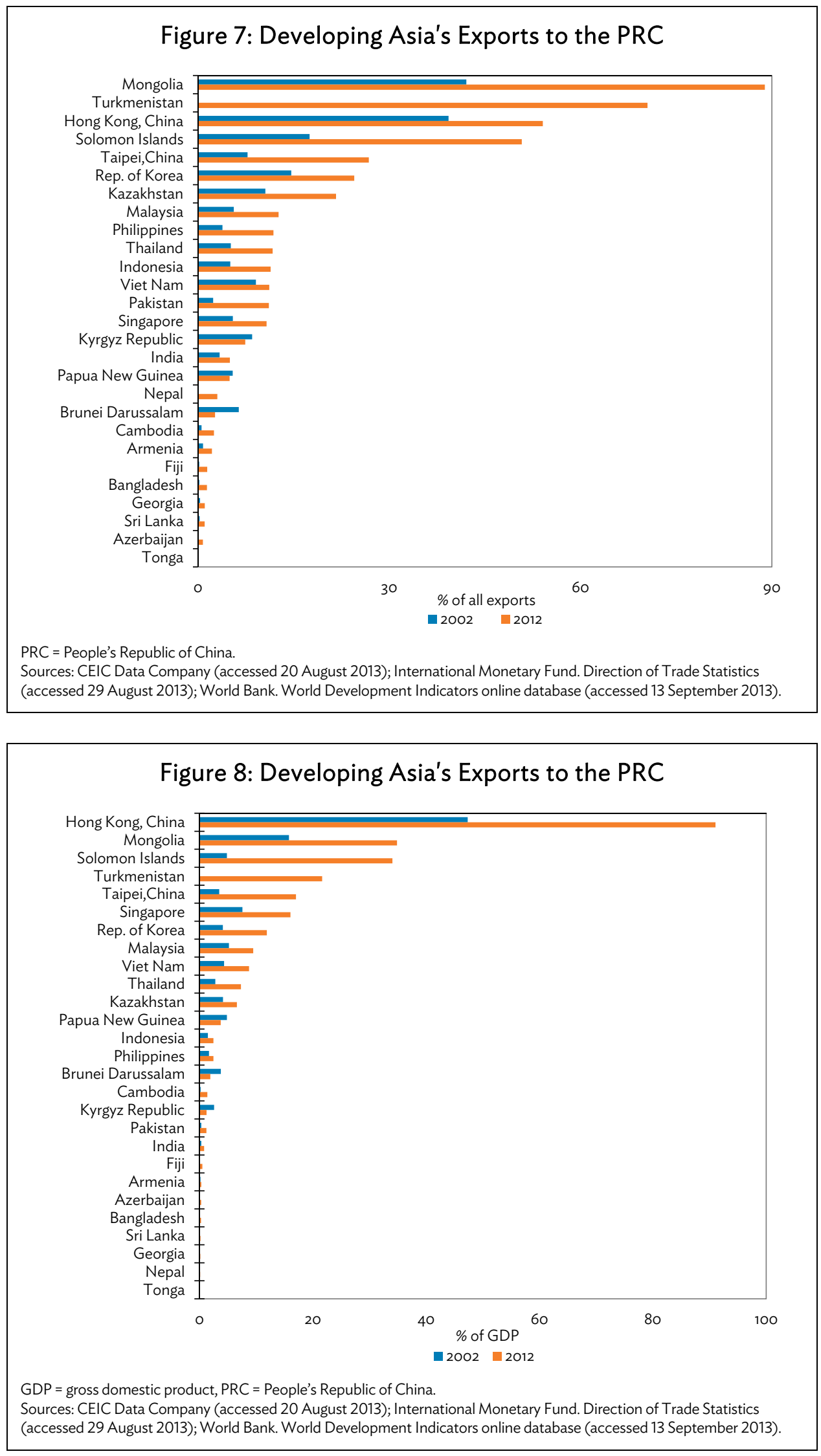


\section{THE IMPACT OF THE PEOPLE'S REPUBLIC OF CHINA SLOWDOWN ON GROWTH IN ASIA: AN EMPIRICAL ASSESSMENT}

Because the growth slowdown in the PRC commenced in 2011-2012, the empirical analysis uses data up to those years to gauge the immediate impact of slower PRC growth on the region.

\section{A. The Trade Channel Approach}

As noted above, trade is likely to be the primary channel of spillover effects from the PRC slowdown on the rest of Asia. How GDP growth in the PRC spills over to affect trade is examined through panel data analysis using the methodology in Ahuja and Nabar (2012). Spillover from the PRC to a trading partner is measured as the product of the partner's exports to the PRC as a share of its GDP and the PRC GDP growth rate. The trading partner's terms of trade growth rate, its lagged GDP growth rate, and an index for macroeconomic volatility are included in the analysis to control for changes in trade prices and to capture dynamic macroeconomic instability since the onset of the global financial crisis.

Model specification: Panel Data Analysis with a Fixed Effect Model

$$
G D P_{i t}^{g r}=\alpha+\beta S P_{i t}^{C}+\gamma T o T_{i t}+\delta V T_{i t}+\eta_{i}+\epsilon_{t}+v_{i t}
$$

where

$$
\begin{aligned}
& G D P_{i t}^{g r}: G D P \text { growth rate of } i \text { at } t \\
& S P_{i t}^{C}=\left[\left(\frac{\text { Total exports to } P R C_{i t}}{G D P_{i t}}\right) * P R C_{t}^{g r}\right] \\
& P R C_{t}^{g r}: P R C G D P \text { growth rate at } t \\
& T o T_{i t}: \text { Annual percentage change in terms of trade of } i \text { at } t \\
& V T_{i t}: \text { volatility of } i \text { at } t, \text { standard deviation of GDP over moving } 5 \text {-year windows }
\end{aligned}
$$

The estimated spillover impact of a PRC slowdown on the rest of developing Asia is clearly significant, and its impact became more substantial after the global crisis (Table 1). In 2012, a 1 percentage point decline in PRC growth slows growth in Asia by 0.128 percentage point. By way of comparison, a 1 percentage point decline in US growth slows growth in Asia, including the PRC, by 0.31 percentage points. However, the PRC impact becomes considerably greater in the postglobal crisis period (2007-2012). More specifically, growth in Asia falls by 0.25 percentage points. Healthy growth in exports to a robust PRC helped the region cope with the advanced economies slowdown (Figure 9). By the same token, however, the PRC slowdown will deliver a negative shock to the rest of developing Asia. 
Table 1: Panel Analysis with a Fixed Effect Model: The Effect of a PRC Slowdown

\begin{tabular}{l|r|r}
\hline \multirow{3}{*}{ Variables } & $(1)$ & \multicolumn{1}{|c}{$(2)$} \\
\cline { 2 - 3 } SP & $2002-2012$ & $2007-2012$ \\
& $0.0128^{* * *}$ & $0.0250^{* * *}$ \\
ToT & $(0.00448)$ & $(0.00790)$ \\
& 0.0264 & 0.00133 \\
VT & $(0.0254)$ & $(0.0331)$ \\
& $-0.303^{* *}$ & $-0.476^{* *}$ \\
Constant & $(0.137)$ & $(0.231)$ \\
& $5.438^{* * *}$ & $4.259^{* * *}$ \\
Observations & $(0.619)$ & $(1.122)$ \\
R-squared & & \\
Number of countries & 297 & 162 \\
\hline
\end{tabular}

PRC = People's Republic of China.

Source: ADB estimates.

\section{Figure 9: Exports from Developing Asia to the US and the PRC}

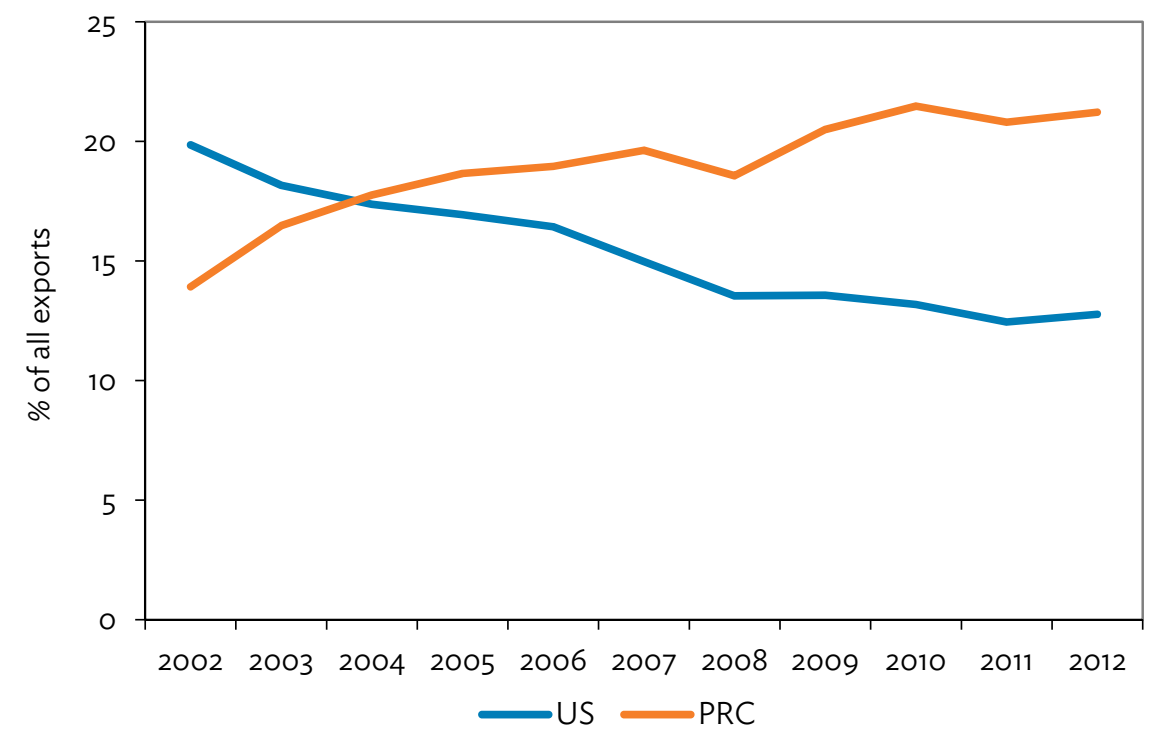

PRC = People's Republic of China, US = United States

Source: ADB estimates based on data from CEIC Data Company (accessed 20 August 2013).

While spillover is significant for developing Asia as a whole, it varies substantially across subregions (Figure 10). It is biggest in East Asia. Hong Kong, China; the Republic of Korea; Mongolia; and Taipei,China have rapidly expanded their trade with the PRC over the past decade. The growth in trade between the PRC and Southeast Asia has been powered not only by economic expansion in the PRC but also by a free trade agreement concluded in 2010. Total trade between the PRC and Southeast Asia has grown more than thirtyfold in the past 10 years, and the PRC has become Southeast Asia's largest trading partner. A 1 percentage point reduction in PRC growth pulls down the weighted average growth rates of East, Southeast, and Central Asia by 0.63, 0.17, and 0.14 percentage 
points, respectively. The effect is more limited in the Pacific, and more limited still in South Asia. The results are consistent with the observation that East and Southeast Asia have much closer economic links with the PRC than does South Asia.

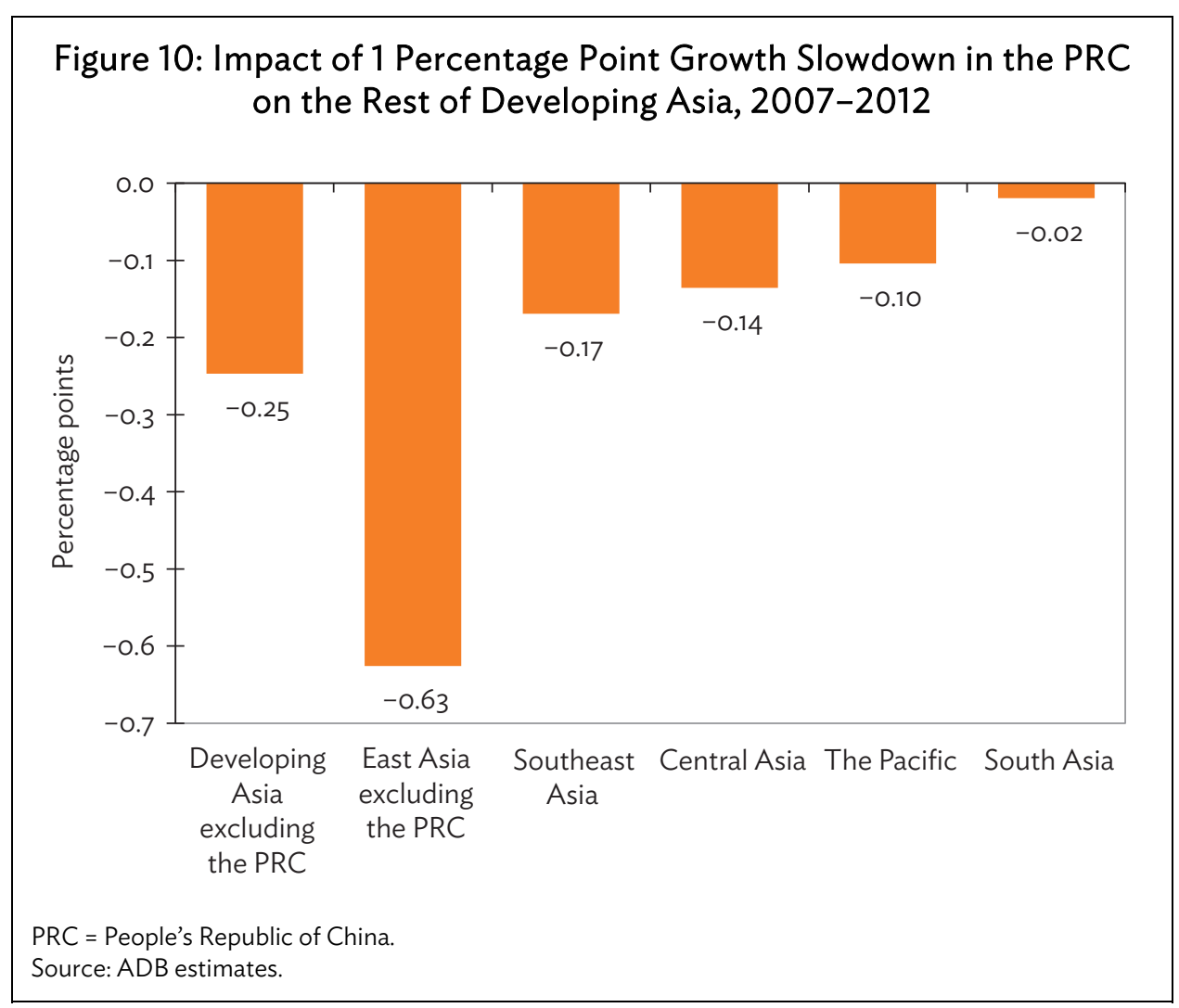

Turning to individual economies, the most heavily exposed economy is Hong Kong, China. Its trade with the PRC exceeded 90\% of its GDP in 2011 and 2012. A 1 percentage point slowdown in the PRC may slow growth in Hong Kong, China by more than 2 percentage points. The adverse effect will also be large for Mongolia; the Republic of Korea; Singapore; and Taipei,China, all of which depend heavily on exports to the PRC and hence are vulnerable to a PRC slowdown (Figure 11). On the other hand, the impact on Southeast Asia's largest economy, Indonesia, is much more muted, despite its large exports to the PRC of natural resources, including coal, tin, rubber, cocoa, and palm oil. The likely reason is that domestic demand plays a relatively large role in growth in Indonesia, which also helps to explain the limited effect on the Philippines. 


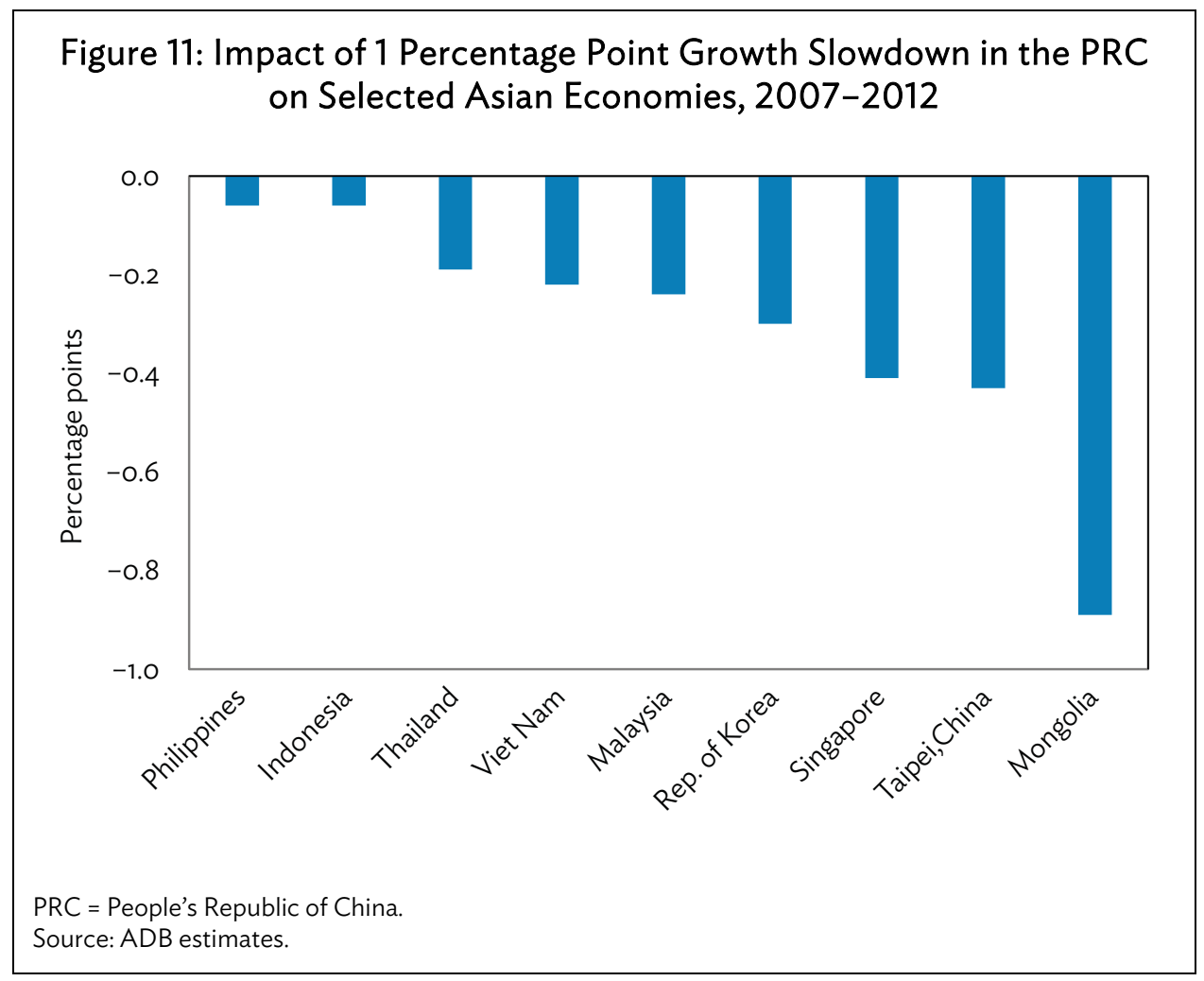

\section{B. Global Vector Autoregressive Analysis}

Results from a global vector autoregressive (GVAR) model can provide a robustness check for the results produced by the single equation approach of the previous section. The model set out in Dees et al. (2007) provides a compact statistical view of the global economic linkages by imposing sufficient discipline to shed light on the relative strength of spillovers from the PRC. As such, relative to a single equation approach, the GVAR model provides a more holistic view of how macrovariables relate across different economies in the model. In particular, it captures more economic linkages than just the trade channel.

Under this model, spillovers are assessed through generalized impulse response functions that consider shocks to an equation in the GVAR system, by exploiting the estimated historical correlation between shocks. The resulting complexity of dynamics comes, however, at the cost of structural identification that makes the underlying structural features of the economy indistinguishable. Although this shortcoming inhibits its use to generate policy counterfactuals, the model is still adequate for measuring international linkages, including spillover.

The data-intensive structure of the model restricts the current focus to spillover from the PRC to SEA economies covered in it-Indonesia, Malaysia, the Philippines, Singapore, and Thailand-based on the variance-covariance matrix from the quarterly data estimation. ${ }^{2}$

2 For the detailed structure of the variant of GVAR model used in this estimation, see Dees et al. (2007). The model is estimated using the GVAR Toolbox 1.1 (Smith and Galesi 2011). The GVAR Toolbox 1.1 is available at https://sites.google.com/site/gvarmodelling/gvar-toolbox 
The resulting generalized impulse response functions from the estimation are used to gauge the strength of spillover from a GDP growth decline in the PRC into SEA economies a year after impact. It is quite substantial. Absent any other disturbance, GDP being 1 percentage point less than baseline in the PRC tends to reduce SEA output by about 0.25 percentage points from its baseline in the same year. The spillover from the PRC is largest for Malaysia, where the effect could reach a magnitude almost 0.4 as large as in the PRC within a year (Figure 12). The second largest spillover, to Singapore, is just slightly less than that of Malaysia. The magnitude of spillover is somewhat smaller to Indonesia (a decline 0.3 as large as the original shock) and Thailand (0.2). The Philippines appears to be the least vulnerable, suffering no significant spillover from the PRC.

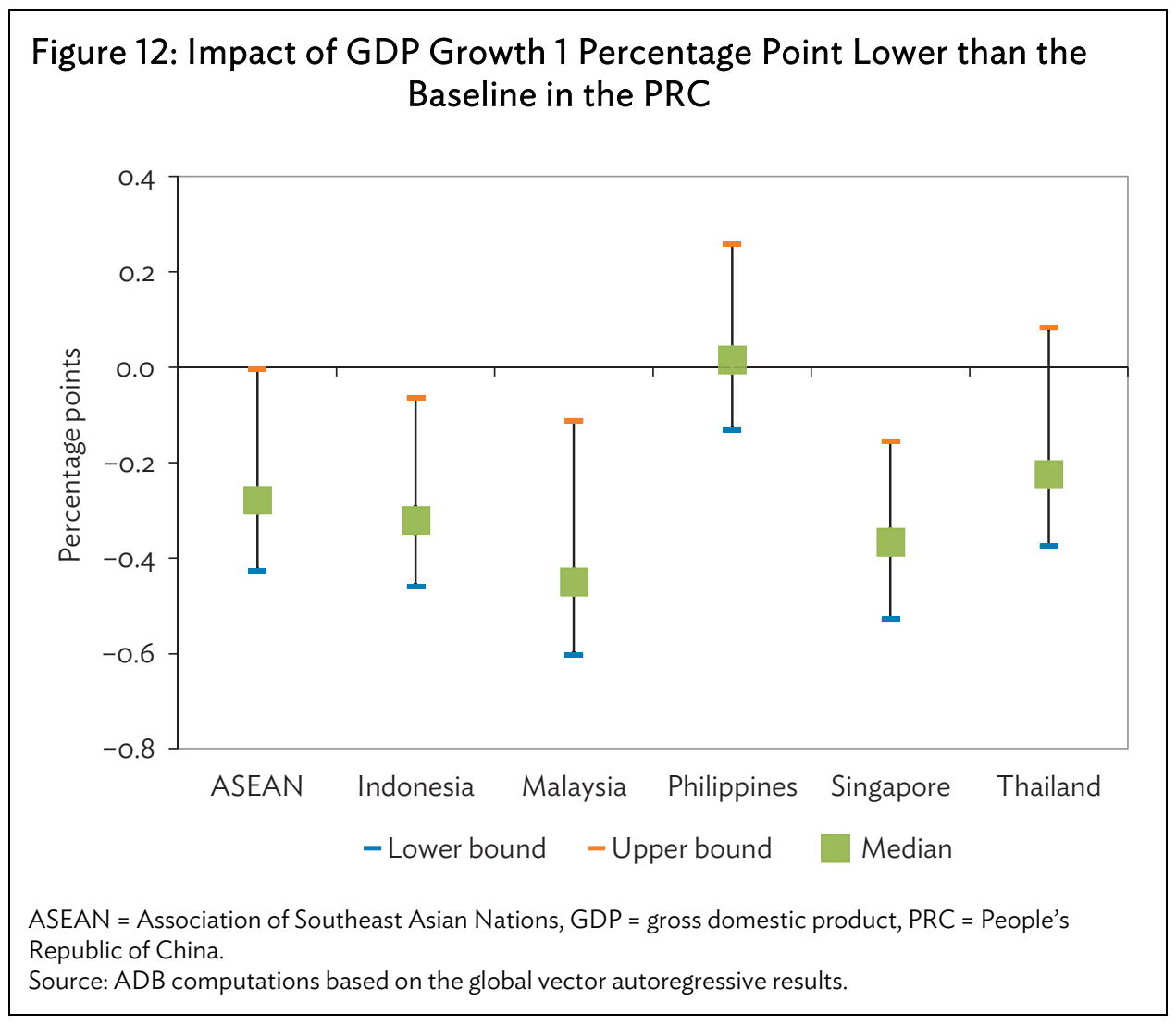

\section{Further Discussion of the Empirical Results}

The magnitude of spillover effects estimated using the single equation approach and the GVAR system are largely comparable for SEA economies. The impact of a 1 percentage reduction in PRC growth relative to the baseline is a tad lower than that of the GVAR system: -0.17 in the former and -0.25 in the latter.

These figures suggest that slower growth in the PRC would have sizable spillover implications for other Asian economies, mostly through the trade channel, in line with the increasing importance of the PRC as an export market. The somewhat larger spillover estimates of the GVAR model suggest that there are some additional secondary effects beyond trade after slower growth in the PRC felt by the other economies considered in the system. These additional effects were muted in the single equation approach because the PRC slowdown does not find its way to affect other variables that may also influence the growth rate of the other economies. 
Comparing the results of the two analytical approaches also reveals that the channels through which slower growth in the PRC affects growth in other Asian countries are not uniform. While the trade channel is dominant for some economies, secondary effects may amplify the impact on some other economies. This is suggested by contrasting, for example, Singapore and Malaysia. While the direct trade effect is larger for Singapore than for Malaysia, large secondary effects mean that total growth effect is larger for Malaysia. This suggests that the secondary contagion effects of the PRC slowdown are significant in some Asian economies.

The magnitude of the spillover can also be used to gauge the probable impact of slower PRC growth on growth in other economies in developing Asia. Taking SEA economies as an example, absent any policy response from SEA authorities, PRC growth dropping below its potential would induce a drop in SEA growth below its potential to an extent approximately proportional to the spillover magnitudes estimated above.

To illustrate the median effect of a slowdown in the PRC on SEA growth, note that, prior to the global financial crisis, the PRC grew faster than $10 \%$ a year on average and Southeast Asia historically grew at an average of $6 \%$. Since the global crisis, PRC growth momentum has weakened, and the PRC is now likely to grow at about 7\% or even lower. Growth of 1 percentage point lower than the historical rate in the PRC could, absent any other disturbance, reduce the SEA combined GDP growth to about 0.25 points less than its historical rate. This implies that future growth will be below historical potential growth. If PRC future potential growth declines by 3 percentage points to $7 \%$ per annum, SEA future potential growth could fall by 0.75 percentage points, to $5.25 \%$ per annum. Therefore, slower growth in the PRC may be one of the important drivers behind the slower growth trends currently observed in the SEA economies.

\section{Knock-on Effects from Further Slowdown in the People's Republic of China in 2013-2014}

To shed light on how the recent slowdown in the PRC affected economic growth in Southeast Asia, we perform an out-of-sample analysis to tease out the effect of slower growth in the PRC from the recent growth performance of selected SEA economies. For this purpose, annual growth trends in the PRC and the six largest SEA economies-Indonesia, Malaysia, the Philippines, Singapore, Thailand, and Viet Nam-in the past couple of decades were used to compute the counterfactual growth rates for each economy in 2013 and $2014 .{ }^{3}$

The counterfactual growth rates are used to gauge the extent to which actual growth rates in 2013 and 2014 deviate from their trends for each economy. Table 2 shows the estimated gap between the actual and trend-based potential growth rates based on this calculation. The negative figures suggest that the actual growth rate fell short of what would have been expected had growth followed its historical trend. The opposite is true for the positive numbers in the table.

3 The trends are established by estimating an Auto Regressive process of degree $1(\operatorname{AR}(1))$ with trend of the log of output of each economy using data up to 2012. The estimated parameters are used to derive the growth trend of each economy as follows: $\left(y_{t}-y_{t-1}\right)=a_{1}+a_{2}\left(y_{t-1}-y_{t-2}\right)$, where $\left(y_{t}-y_{t-1}\right)$ is the growth rate at time $t$; and $a_{1}$ and $a_{2}$ are the estimated trend coefficient and slope coefficient for the series, respectively. Estimations exploit annual data from 1990 to 2012 for the PRC and Viet Nam, and from 1999 to 2012 for the other SEA economies to avoid data distortions during the Asian financial crisis episode. 
Table 2: Estimated Growth Gap, 2013 and 2014

(\%)

\begin{tabular}{l|r|r}
\hline Economy & 2013 & 2014 \\
\hline PRC & -1.5 & -2.2 \\
Indonesia & -0.2 & -0.9 \\
Malaysia & -0.5 & 1.0 \\
Philippines & 2.9 & 1.1 \\
Singapore & -0.5 & -2.8 \\
Thailand & -1.9 & -3.3 \\
Viet Nam & -1.4 & 0.0 \\
\hline
\end{tabular}

PRC = People's Republic of China. Source: ADB estimates.

Taking the PRC growth gaps for 2013 and 2014 as negative shocks to the economy's GDP in that period, the spillover coefficients can be used to isolate the effects of the PRC slowdown on SEA economies. In particular, the spillover coefficient from the single equation approach can be used to isolate the trade effect, and that from the GVAR estimate can be interpreted as capturing the total effect of slowdown in the PRC.

Figure 13 displays the effects of the PRC growth slowdown on the six SEA economies in more detail. The effects are not homogenous across economies and seem useful in gauging the different effects underlying the growth dynamics of these economies in 2013-2014. The trade effects and the total effects tend to be similar for Singapore and Thailand, while secondary effects beyond direct trade with the PRC play important roles for Indonesia and Malaysia. The Philippines is the only economy that seems unaffected by the PRC, with only a small trade effect and an insignificant total effect.

Beyond the PRC effects discussed above, Figure 13 suggests that other factors were present in driving the growth dynamics in SEA economies. In 2013, economic growth in Indonesia, Malaysia, and Singapore experienced some positive shocks that mitigated the negative effect from the PRC. On the other hand, weak domestic demand in Thailand and Viet Nam exacerbated the adverse effect of the PRC slowdown.

In 2014, spillover from the slower PRC continued to pull down SEA economies. In Malaysia, the Philippines, and Viet Nam, the drag was dampened by positive shocks. More specifically, rising flows of foreign direct investment into Viet Nam, and robust domestic demand and an export rebound in the Philippines and Malaysia, counteracted the impact of a slower PRC. In contrast, Indonesia, Singapore, and Thailand suffered additional shocks that amplified the adverse PRC effect. Ongoing political instability in Thailand, weak productivity gains in Singapore, and contractionary policies designed to curb current account deficits in Indonesia have all acted as additional drags on economic growth. 


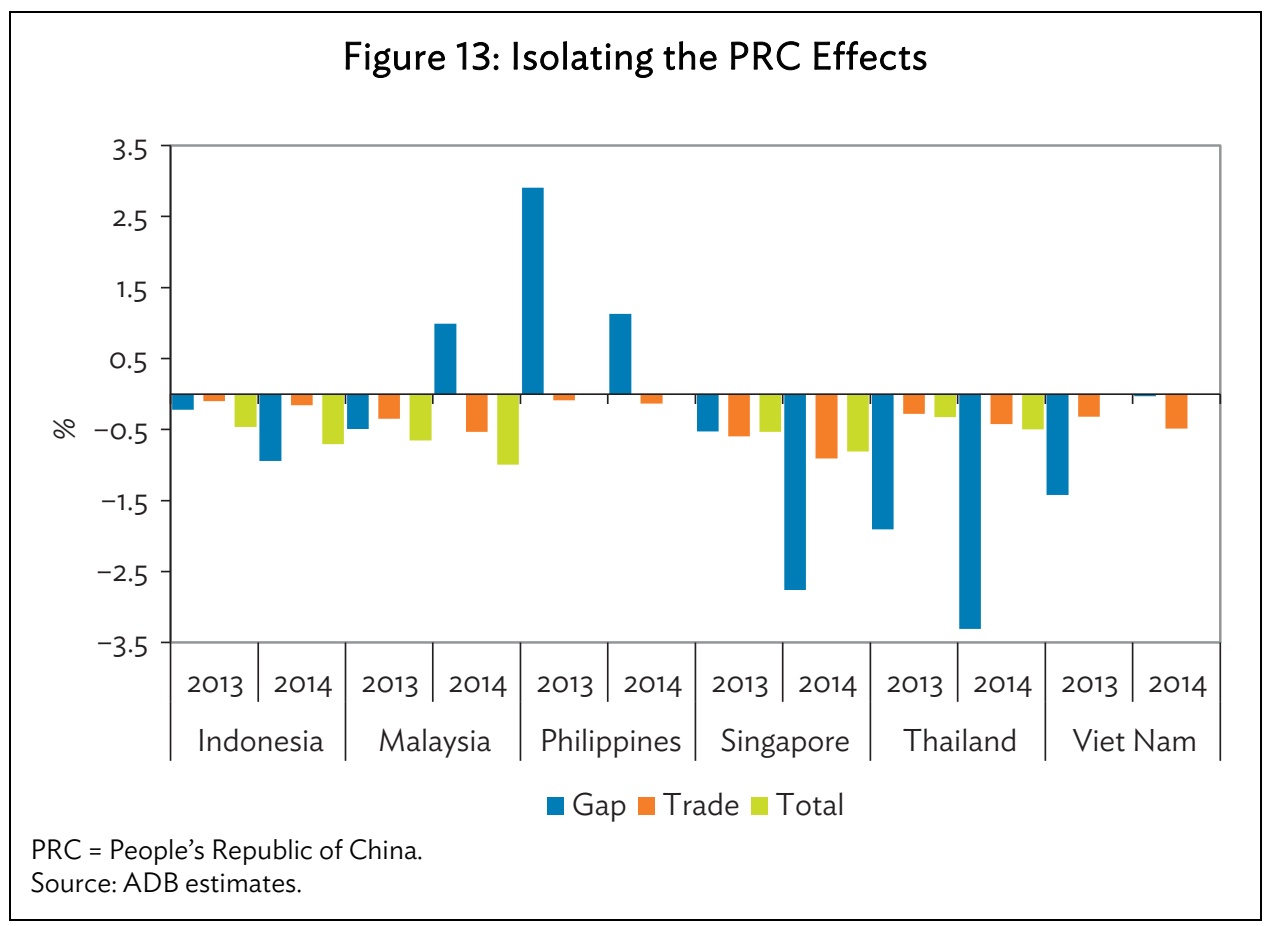

\section{CONCLUDING OBSERVATIONS}

The spectacular rise of the PRC as a global economic force since the initiation of market reforms in 1978 is arguably the single most significant global economic trend in the past few decades. The effects of PRC reintegration into the world economy have been felt loud and clear across the world, in both advanced and emerging markets, and in all continents. The PRC factor has been felt via many channels, including the rising importance of the PRC as a source of outward investment. But the trade channel has been front and center, mirroring a large and growing imprint made as the PRC emerges as a globally significant exporter and importer. The export and growth performance of developing Asia, in particular East and Southeast Asia, benefited a lot from the growing appetite for imports in the PRC, which grew rapidly in tandem with its growth. The two subregions also formed a regional production network with the PRC, exporting manufactured goods all over the world.

Since the global financial crisis of 2008-2009, PRC growth momentum has decelerated in line with the broader trend of slower global growth in the postcrisis period. The PRC slowdown has spawned fears of a sizable drag on global growth, as relentless growth in the PRC before the crisis served as an engine of global growth. The central objective of this paper is to quantify the potential effect of the PRC slowdown on Asian economies using two different methodologies: (i) a singleequation approach that captures the trade channel and (ii) a GVAR model that captures other effects in addition to the trade channel.

Empirical findings from both types of analysis confirm that the PRC deceleration will indeed have a significant negative effect, especially on East and Southeast Asia. However, the effects are not homogenous across countries. An out-of-sample analysis to tease out the effect of slower growth in the PRC from the recent growth performance of selected SEA economies suggests that the PRC effect is contributing to the growth dynamics of this region but does not 
always dominate. In 2013, for example, some positive shocks in Indonesia, Malaysia, and Singapore mitigated the negative effect of the PRC slowdown on their growth, but weak domestic demand in Thailand and Viet Nam exacerbated it.

However, it is important to look beyond the short run and think about the medium- and long-term implications of slower growth in the PRC. Above all, PRC deceleration represents a welcome, healthy, and natural transition to a slower but more sustainable growth path. Unsustainably rapid growth would deliver gains in the short run but could culminate in a major crisis and seriously harm growth prospects over a longer horizon. Therefore, slower but more sustainable growth may in fact be beneficial for Asian economies even though it is likely to entail sizable short-term costs, as evident in this analysis. Further, the PRC slowdown is partly related to an ongoing process of structural change, from export- and investment-led growth to domestic demand- and consumption-led growth. Such structural change could open up new export opportunities for Asia and the world, especially for exporters of consumer goods, even though it will dampen prospects for exporters of investment goods. In sum, the adverse effect of the PRC slowdown may be offset to some extent by positive factors such as expanded exports of consumer goods. 


\section{REFERENCES*}

Ahuja, A., and M. Nabar. 2012. Investment-Led Growth in China: Global Spillovers. IMF Working Paper WP/12/267.

Dees, S., F. di Mauro, M. H. Pesaran, and L. V. Smith. 2007. Exploring the International Linkages of the Euro Area: A Global VAR Analysis. Journal of Applied Econometrics. 22 (1). pp. 1-38.

Eichengreen, B., D. Park, and K. Shin. 2012. When Fast Growing Economies Slow Down: International Evidence and Implications for China. Asian Economic Papers. 11 (1). pp 42-87.

2014. Growth Slowdowns Redux. Japan and the World Economy. 32. pp. 65-84.

Li, P., and F. Lou. 2015. China's Potential Economic Growths during 2015-2025 under Different Scenarios. China Economist. 10 (2). pp. 82-99.

Park, D., and K. Shin. 2010. Can Trade with the People's Republic of China Be an Engine of Growth for Developing Asia? Asian Development Review. 27 (1). pp. 160-81.

- 2011. People's Republic of China as an Engine of Growth for Developing Asia? Asian Economic Papers. 10 (2). pp. 120-163.

Smith, L. V., and A. Galesi. 2011. GVAR Toolbox 1.1. https://sites.google.com/site/gvarmodelling/ gvar-toolbox

Yuan, F., C. Chen, P. Zhang, X. Liu, and M. Lu. 2013. China's Transition Phase and Long-Term Development Path, Efficiency and Growth Rates. China Economist. 8 (2). pp. 28-43.

* ADB recognizes "China” as the People's Republic of China. 


\section{How Growth Deceleration in the People's Republic of China Affects Other Asian Economies: An Empirical Analysis}

How does growth deceleration in the PRC affect other Asian economies? The paper employs two empirical methodologies to examine the question: A single-equation approach that captures the trade channel and a global vector autoregressive model that captures the effects beyond just the trade channel. The results confirm the non-negligible effect of the PRC deceleration on other economies, especially on East and Southeast Asia. The effect, however, is not always the dominating factor.

\section{About the Asian Development Bank}

ADB's vision is an Asia and Pacific region free of poverty. Its mission is to help its developing member countries reduce poverty and improve the quality of life of their people. Despite the region's many successes, it remains home to the majority of the world's poor. ADB is committed to reducing poverty through inclusive economic growth, environmentally sustainable growth, and regional integration.

Based in Manila, ADB is owned by 67 members, including 48 from the region. Its main instruments for helping its developing member countries are policy dialogue, loans, equity investments, guarantees, grants, and technical assistance. 